\title{
SOLAR ENERGY USE FOR WATER PRE-HEATING IN BOILERS OF AGRO-INDUSTRIES
}

\author{
RAFAEL CELUPPI ${ }^{1}$, JAQUELINE SCAPINELLO ${ }^{2}$, FELIPE G. D. ANDRADE ${ }^{3}$, \\ JAIME H. P. REVELLO ${ }^{4}$, JACIR DAL MAGRO ${ }^{5}$
}

\begin{abstract}
Energy consumption in the world has been growing every year. The industrial sector represents $27.32 \%$ of the world energy demand. Heating systems that use solar energy may contribute with a percentage of the total energy required by industries. This work aimed to study the use of vacuum solar collectors for water pre-heating in boilers. We used four collectors installed according to NBR 15,569; water flow through the tubes was $0.058 \mathrm{~L} / \mathrm{s}$, and temperature in the inlet and outlet pipes was measured. Results showed that instantaneous radiation, and inlet fluid and room temperatures are variables that influence the process, reaching water maximum temperature in the solar collector outlet of $97.9{ }^{\circ} \mathrm{C}$, and efficiency of approximately $65 \%$ for most experiments. For the financial viability evaluation, the payback study was applied, which resulted in 4; 7 and 5 years, for the respective sources: firewood, LPG (liquefied petroleum gas), and electricity. Regarding the calculation of the annual contribution to the reduction of greenhouse gases, it was, respectively, 2.162 and $356 \mathrm{~kg}$ of $\mathrm{CO}_{2}$ per $\mathrm{m}^{2}$ of collector tubes, in comparison with firewood and LPG.
\end{abstract}

KEYWORDS: solar collector, water heating, energy efficiency.

\section{USO DE ENERGIA SOLAR NO PRÉ-AQUECIMENTO DE ÁGUA EM CALDEIRAS PARA AGROINDÚSTRIAS}

RESUMO: O consumo de energia no mundo vem crescendo a cada ano, e o setor industrial representa $27,32 \%$ da demanda de energia mundial. Sistemas de aquecimento que usam energia solar podem contribuir com uma percentagem da energia total requerida pelas indústrias. Este trabalho teve por objetivo estudar o uso de coletores solares a vácuo no pré-aquecimento de água para caldeiras de agroindústrias. Foram utilizados quatro coletores instalados de acordo com a NBR 15.569, uma vazão da água por meio dos tubos de 0,058L/s e foi medida a temperatura na entrada e na saída dos tubos. Os resultados obtidos mostraram que a radiação instantânea, temperatura de entrada do fluido e temperatura ambiente são variáveis que mais influenciam no processo, chegando a uma temperatura máxima para água, na saída do coletor solar, de $97,9^{\circ} \mathrm{C}$, e eficiência de aproximadamente $65 \%$ para a maioria dos experimentos realizados. Na avaliação da viabilidade financeira, foi realizado o estudo de payback descontado, que resultou em 4; 7 e 5 anos, para os respectivos combustíveis: lenha, GLP (gás liquefeito de petróleo) e energia elétrica. Com relação ao cálculo da contribuição na redução anual de gases do efeito estufa, foi de, respectivamente, 2.162 e $356 \mathrm{~kg}$ de $\mathrm{CO}_{2}$ por $\mathrm{m}^{2}$ de tubos coletores, quando comparado com lenha e o GLP.

PALAVRAS-CHAVE: coletor solar, aquecimento de água, eficiência energética.

\footnotetext{
${ }^{1}$ Eng $^{0}$ Químico, Mestrando em Ciências Ambientais, Universidade Comunitária da Região de Chapecó, UNOCHAPECÓ, Chapecó SC, Fone: (49) 3321-8090, celuppi@unochapeco.edu.br.

${ }^{2}$ Doutoranda em Eng ${ }^{\mathrm{a}}$ Química, Profa. da Área de Ciências Exatas e Ambientais, UNOCHAPECÓ, jaquescapinello@gmail.com

${ }^{3}$ Estudante de Eng ${ }^{\mathrm{a}}$ Química da Universidade Comunitária da Região de Chapecó, UNOCHAPECÓ, felipega@unochapeco.edu.br

${ }^{4}$ Eng ${ }^{\circ}$ Químico, Prof. Dr., Universidade Federal da Grande Dourados, UFGD, Dourados - MS, JaimeRevello@ufgd.edu.br

${ }^{5}$ Químico, Prof. Dr., Programa de Pós-Graduação em Ciências Ambientais, jacir@unochapeco.edu.br

Recebido pelo Conselho Editorial em: 20-5-2013

Aprovado pelo Conselho Editorial em: 13-1-2014
} 


\section{INTRODUCTION}

The search for greater energy efficiency, along with policies of clean development mechanism, has encouraged the study of new techniques for power generation using renewable energy sources with lower generation of pollutants (DINIZ \& BERMANN, 2012). Among the alternative energy sources, solar energy is becoming more popular, especially for residential water heating, being a cost-effective alternative to the use of electricity and natural gas (GOLDEMBERG \& LUCON, 2007; LUNA et al., 2008; MEDEIROS, 2008; OLIVEIRA et al., 2008; ALTOÉ et al., 2012).

Energy obtainment in most countries of the world is performed by thermoelectric power plants through burning of fuel oils derived from petroleum, natural gas, and coal (IEA, 2011; ABRAMOVAY, 2010). Processes of energy generation through burning of these compounds, in addition to the release of high loads of atmospheric pollutants, contribute to global warming, generating, among other pollutants, high amounts of carbon dioxide and carbon monoxide, which are the main gases that cause the greenhouse effect (MENDES \& RODRIGUES FILHO, 2012). On the other hand, the power generated by hydroelectric plants also results in a great environmental impact, promoting the displacement of large numbers of people and seriously compromising the biodiversity of that ecosystem (BERMANN, 2012; QUEIROZ \& MOTTA VEIGA, 2012; BARON \& RENCK, 2012).

The challenge of mitigating imminent risks arising from climate change embraces not only governments, but the civil society and companies; therefore, it is necessary to develop and establish techniques that reduce the concentration of gases causing the greenhouse effect in the atmosphere. In the industry, the use of solar energy has been little explored since the energy obtained via solar collectors may be used for fluid pre-heating, what greatly reduces the amount of fuel material burnt in boilers (KALOGIROU, 2004; ABRAMOVAY, 2010).

The main barriers to the implementation of a solar heating system of high performance are the lack of data on collectors when high temperatures are employed, and its actual efficiency under different temperature conditions. In this sense, this study aimed to identify relevant parameters of fluid heating for solar power systems as well as the main process responses. In addition to tests of heat transfer, economic viability studies were performed by calculating the return time and rate on the investment.

\section{MATERIAL AND METHODS}

\section{Photothermal collector implementation}

Four solar tubular collectors (Apricus brand, model AP 30), with aperture area of $2.83 \mathrm{~m}^{2}$ and total area of $4.4 \mathrm{~m}^{2}$, were used. Each collector consists of 20 borosilicate 3.3 vacuum tubes with absorbing surface of aluminum nitrate on aluminum (Al-N/Al). The collectors were installed in series, according to NBR 15569 (ABNT, 2008), in a rural area of Chapecó, Santa Catarina State, Brazil (27 $07^{\prime} 54^{\prime \prime} \mathrm{S}$ and $\left.52^{\circ} 70^{\prime} 88^{\prime \prime} \mathrm{W}\right)$. The collectors were oriented north with a $37^{\circ}$ inclination, which was defined by the equipment structure configuration within the tolerance of the local latitude $+10^{\circ}$ to optimize the use of solar energy throughout the year. Such configuration was performed according to the manufacturer's instructions and, also, literature data (APRICUS, 2012; ARRUDA, 2004). Water flow inside the solar collector tubes was $0.0598 \mathrm{~L} / \mathrm{s}$, obtained by a globe valve and a centrifugal pump. Temperature sensors, of the PT 100 type, were installed at the beginning and end of each collector, connected to a data acquisition board, and used for periodic temperature monitoring. Figure 1 shows a schematic representation of the experiment performed with tubular solar collectors and accessories. 


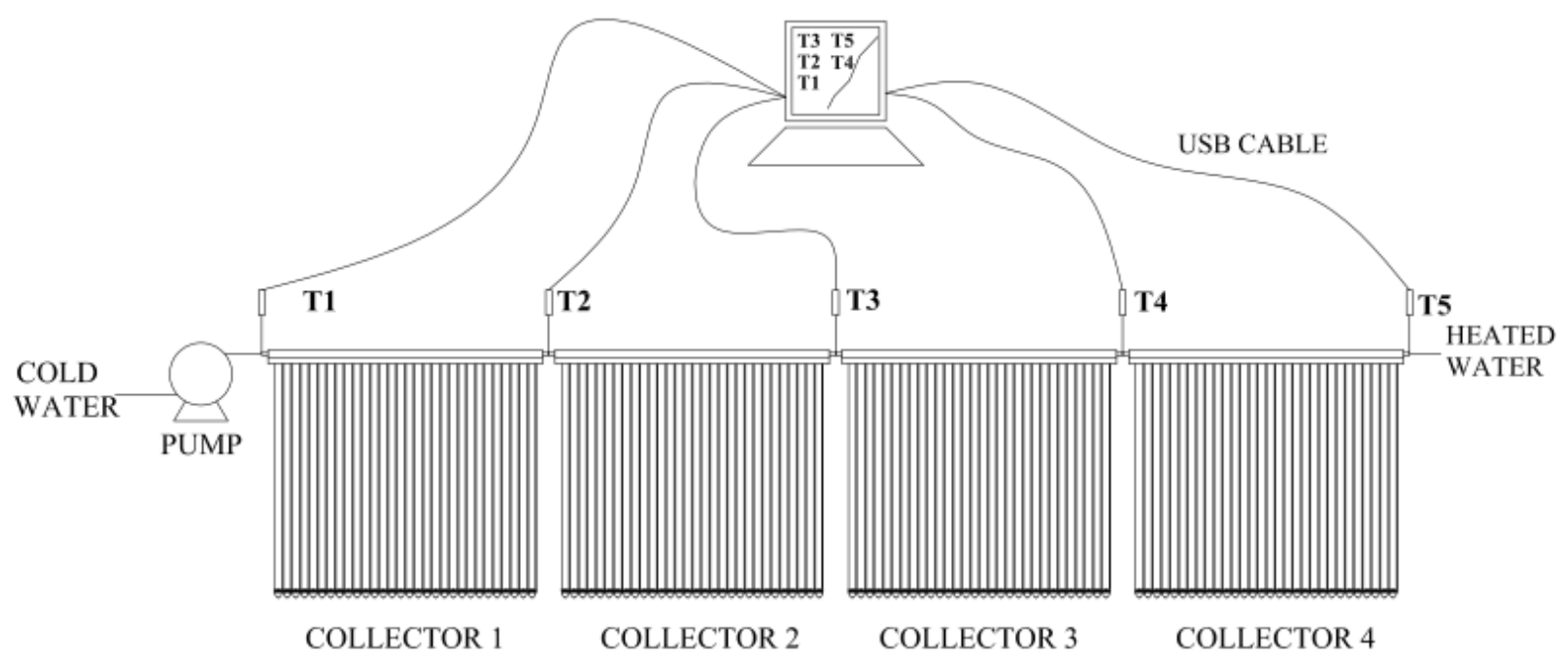

FIGURE 1. Schematic representation of the experiment performed with solar collectors in series and accessories.

Other process data were obtained from INMET-Xanxerê (Santa Catarina State), such as room temperature and instantaneous solar radiation; data of annual mean daily radiation, used in the economic evaluation, were obtained from RETScreen 4 software (RETScreen ${ }^{\circledR}, 2012$ ).

\section{Efficiency of the solar water heating system}

Calculation of system efficiency was carried out according to LEEPHAKPREEDA (2010) so that the efficiency expresses the heat fraction from the incident solar radiation that is absorbed by the working fluid. The heat absorbed by water from the radiation is calculated by the energy balance in the system. Equation (1) is used to achieve the heat flow:

$$
\text { Qabsorbed }=m C\left(T_{f}-T_{i}\right)
$$

where,

$\mathrm{C}$ - specific heat for water evaluated at the mean temperature, $\mathrm{J} / \mathrm{kg} \mathrm{K}$;

$\mathrm{m}$ - mass flow, $\mathrm{kg} / \mathrm{s}$, and

$\mathrm{Tf}$ and $\mathrm{Ti}$ - inlet and outlet temperatures of each collector.

Equation (2) describes the efficiency of collectors according to local radiation:

$$
\mathbf{\eta}=\frac{\mathbf{Q}_{\mathrm{absorbed}}}{\mathbf{Q}_{\text {solar energy }} \times \text { Collecting area }} \mathbf{1 0 0}
$$

where,

Qabsorbed - heat absorbed by water inside the collector, and

Qsolar energy - instantaneous solar radiation converted into heat, $\mathrm{kJ} / \mathrm{m}^{2}$.

Instantaneous solar radiation data were obtained at INMET (National Institute of Meteorology), in Xanxerê, and the collecting area varies according to type and number of the used collectors. It should be noted that the conversion efficiency is proportional to the ratio between the working fluid mean temperature and room temperature, for a given solar radiation.

Values of solar radiation are very variable along the day. Thus, the calculation of the reduced temperature ( $\left.\mathrm{T}_{\mathrm{Red}}\right)$ is commonly applied, as it is a variable of high relevance used in the analysis of heat transfer (BERGMAN et al., 2011; QUERINO et al., 2011). It relates the mean temperature 
(Tm), obtained from the collector inlet and outlet temperatures, to the room temperature (TR) and instantaneous solar radiation (G), as shown by eq.(3):

$$
\mathbf{T}_{\text {Red }}=\frac{\mathbf{T}_{\mathrm{m}}-\mathbf{T}_{\mathrm{R}}}{\mathbf{G}}
$$

\section{Economic evaluation}

For economic viability analysis, some indices were used, such as return time on capital (payback) and net present value (NPV). We used the discounted payback that represents the calculation of return period on investment, considering the discounted cash flows. The result obtained by this calculation shows the number of periods required for the flow of benefits to be equal to the invested capital (ABENSUR, 2012).

The net present value is a technique of capital budget analysis, which takes considers the money value over time and requires the choice of a minimum rate desired by the investor for discount purposes. Via NPV, the possibility of return overcoming by the investment is verified; therefore, the investment decision should be accepted if NPV is positive, and rejected, if it is negative (SILVA \& FONTES, 2005; ABENSUR, 2012; PERES et al., 2009; SANTOS, 2009). The NPV calculation is performed according to Equation (4):

$$
\mathrm{NPV}=\frac{\mathrm{CF}_{0}}{(1+\mathrm{i})^{0}}+\frac{\mathrm{CF}_{1}}{(1+\mathrm{i})^{1}}+\frac{\mathrm{CF}_{2}}{(1+\mathrm{i})^{2}}+\frac{\mathrm{CF}_{3}}{(1+\mathrm{i})^{3}}+\cdots+\frac{\mathrm{CF}_{\mathrm{n}}}{(1+\mathrm{i})^{\mathrm{n}}}
$$

where,

$\mathrm{n}$ - number of periods (years) with invested money in the project;

i - capital cost or hurdle rate, which we considered $10 \%$, and

$\mathrm{CF}$ - the cash flow generated in the period.

The discounted payback was calculated by eq.(5):

$$
\mathrm{PBD}=\frac{\mathrm{CF}_{0}}{(1+\mathrm{i})^{0}}-\left(\frac{\mathrm{CF}_{1}}{(1+\mathrm{i})^{1}}+\frac{\mathrm{CF}_{2}}{(1+\mathrm{i})^{2}}+\frac{\mathrm{CF}_{3}}{(1+\mathrm{i})^{3}}+\cdots+\frac{\mathrm{CF}_{\mathrm{n}}}{(1+\mathrm{i})^{\mathrm{n}}}\right)=0
$$

Using this equation, it may be stated that PBD is that time when the initial investment is equal to the discounted cash flows generated by the project.

After obtaining the efficiency index for the solar collector, and finding the ideal system working conditions, the economic viability analysis was performed for the use of water pre-heating in boilers. This was achieved by comparing solar energy with three conventional sources that are commonly used in the industry: firewood, LPG, and electricity.

\section{RESULTS AND DISCUSSION}

\section{Efficiency of the solar water heating system}

The temperature profile obtained at the inlet and outlet of each collector, shown in Table 1, confirms the system contribution to water heating for both winter and summer. We verified an increase of the fluid temperature according to the increasing amount of collectors with the same radiation and climatic conditions, in the summer and winter time, which justifies the equipment implementation with collectors in series. As any heat transfer that depends on the surface area, an increase number of collection tubes raises the heat exchange surface area, thus the system heat exchanges also increase (GIORGETTI, 2008).

It is possible to notice that the temperatures maintain a mean yield when the inlet temperature does not vary; we observed that, from $7 \mathrm{pm}$ to about $7 \mathrm{am}$, the temperature remains constant because there is no solar heating during the night. For KALOGIROU (2004), solar collectors have a 
decreased efficiency when weather conditions are not favorable, such as cold, cloudy, and/or windy days.

TABLE 1. Data of solar radiation and solar collector inlet and outlet temperatures on different days and times.

\begin{tabular}{lccccccc}
\hline \multirow{2}{*}{ Date - Time } & $\begin{array}{c}\text { Radiation } \\
\left(\mathrm{W} / \mathrm{m}^{2}\right)\end{array}$ & $\mathrm{T} 1$ & $\mathrm{~T} 2$ & $\mathrm{~T} 3$ & $\mathrm{~T} 4$ & $\mathrm{~T} 5$ & $\mathrm{~T}_{\text {room }}$ \\
\hline 02/29 - 2 pm & 690.55 & 39.7 & 44.0 & 48.1 & 53.1 & 58.0 & 26.0 \\
02/29 - 4:20 pm & 774.72 & 40.4 & 45.5 & 50.5 & 55.5 & 60.5 & 31.0 \\
03/03 - 12 pm & 845.27 & 40.0 & 44.8 & 49.9 & 54.9 & 60.4 & 24.5 \\
$03 / 03-5 \mathrm{pm}$ & 730.83 & 36.7 & 41.4 & 46.1 & 50.9 & 55.7 & 28.0 \\
03/05 - 12 pm & 922.22 & 82.1 & 85.6 & 89.8 & 94.1 & 97.9 & 29.0 \\
08/07 - 2 pm & 604.17 & 35.8 & 39.5 & 42.7 & 46.1 & 49.2 & 19.2 \\
08/11 - 2 pm & 621.67 & 38.1 & 42.1 & 45.9 & 49.8 & 53.5 & 22.3 \\
08/16 - 2 pm & 311.39 & 32.6 & 34.5 & 36.3 & 38.0 & 39.5 & 20.4 \\
\hline
\end{tabular}

As shown in Table 1, the solar radiation data vary throughout the day and, therefore, the temperatures recorded from the outlet fluid from each collector also vary. Thus, the calculation of the reduced temperature must be used to facilitate result interpretation and discussion. It was observed that the collector inlet temperature was higher than the room temperature due to the fact the inlets received water from the accumulation system (15,000 liters), which is also heated by a boiler of $15,000 \mathrm{kcal} / \mathrm{h}$, using firewood or biogas as sources, the latter produced in a digester belonging to the property. In Figure 2, it is also possible to observe the season behavior of the solar collector; the first period, from 02/29/2012 to 03/05/2012, obtained the greatest values of incident solar radiation, as well as higher temperatures, of $961.11 \mathrm{~W} / \mathrm{m}^{2}$ and $97.9^{\circ} \mathrm{C}$, respectively, since tests were performed during the hottest season in Southern Brazil (summer). On the other hand, the period from 08/07/2012 to 08/16/2012 showed much lower values of solar radiation and temperatures, when compared with the first period, due to winter environmental characteristics, with lower radiation incidence and milder temperatures.

(A)

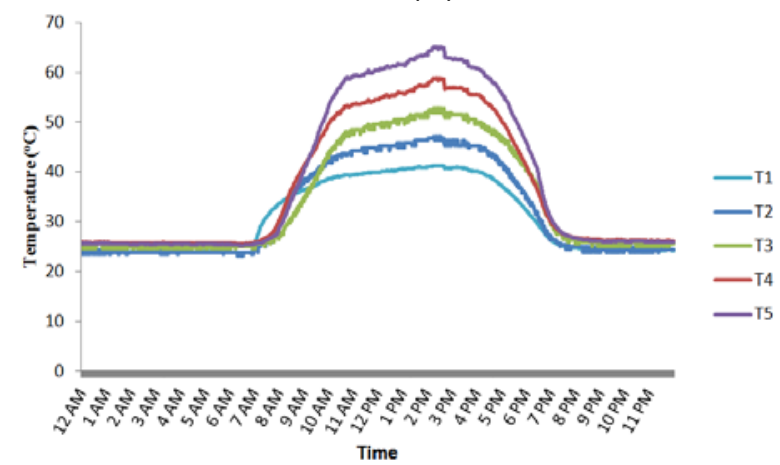

(B)

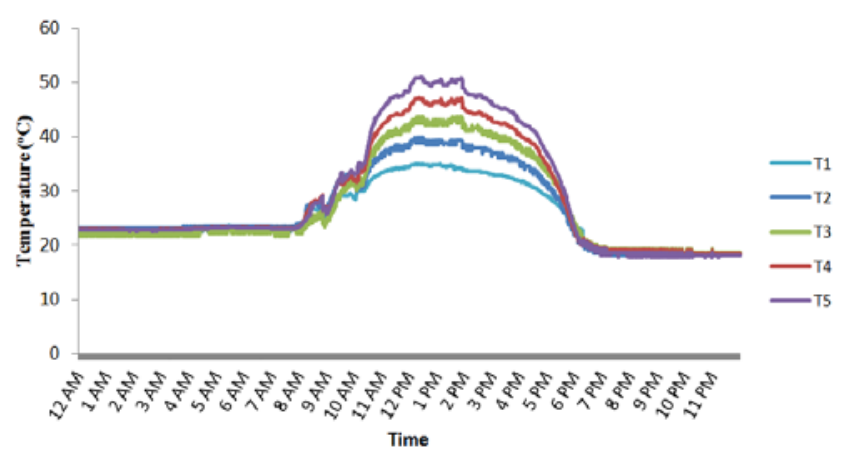

FIGURE 2. Temperature profiles in the solar collector along one day in summer (A) and winter (B).

Regarding the solar collector efficiency, it was observed that it varied according to the environmental conditions; instantaneous radiation, inlet fluid temperature, and room temperature, were the variables that most influenced the process. According to LIN (2006), it is essential to maintain a close difference between the inlet fluid and room temperatures to obtain better collector thermal performance. Figure 3 presents the efficiency graph obtained in the collector regarding the reduced temperature. Considering little variation in the room temperature, it is possible to verify that the reduced temperature is directly proportional to the collector mean temperature, and inversely proportional to the instantaneous solar radiation. 


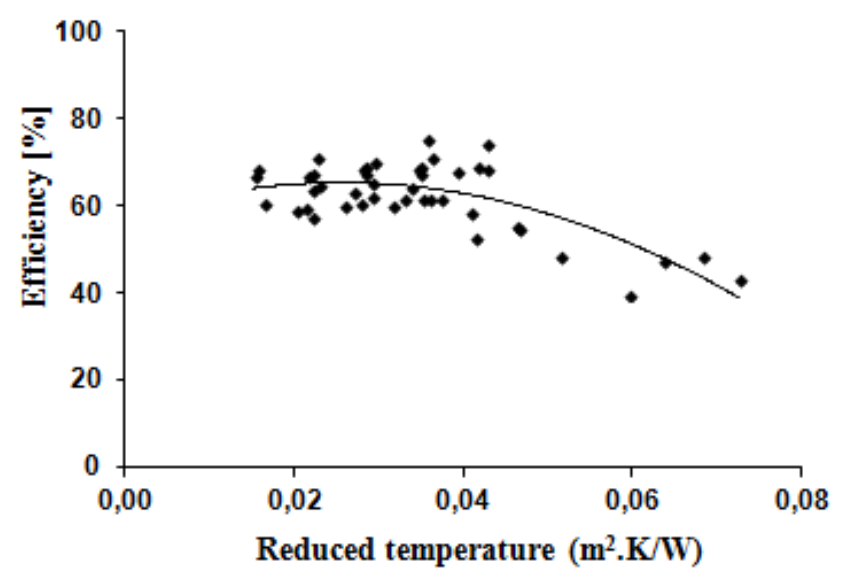

FIGURE 3. Efficiency of the solar collector, according to the reduced temperature, for several experiments.

The efficiency calculation showed that most values are concentrated around $65 \%$ and, also, that only increasing reduced temperatures (up to $0.04 \mathrm{~m}^{2} \mathrm{~K} / \mathrm{W}$ ) promote a significant decrease in the efficiency percentage. These results are encouraging, since studies by LEEPHAKPREEDA (2010) on vacuum solar tube collectors under similar solar radiation, did not achieve greater efficiency than $50 \%$; moreover, for reduced temperatures above $0.01 \mathrm{~m}^{2} \mathrm{~K} / \mathrm{W}$, there was even a further efficiency reduction. This positively highlights the data obtained in this experiment, as vacuum tube collectors were used, which are also known as heat pipes. These collectors have an additional advantage over other solar systems since, in the vacuum one, solar radiation is retained in the tube, with almost no heat loss through the glass.

As the mean inlet fluid temperature directly affects the efficiency of solar collectors, it is possible to verify, for each collector composing the system, that the highest efficiency levels are obtained in the first three collectors, where inlet maximum temperature fluctuates around $50{ }^{\circ} \mathrm{C}$ (Figure 4).

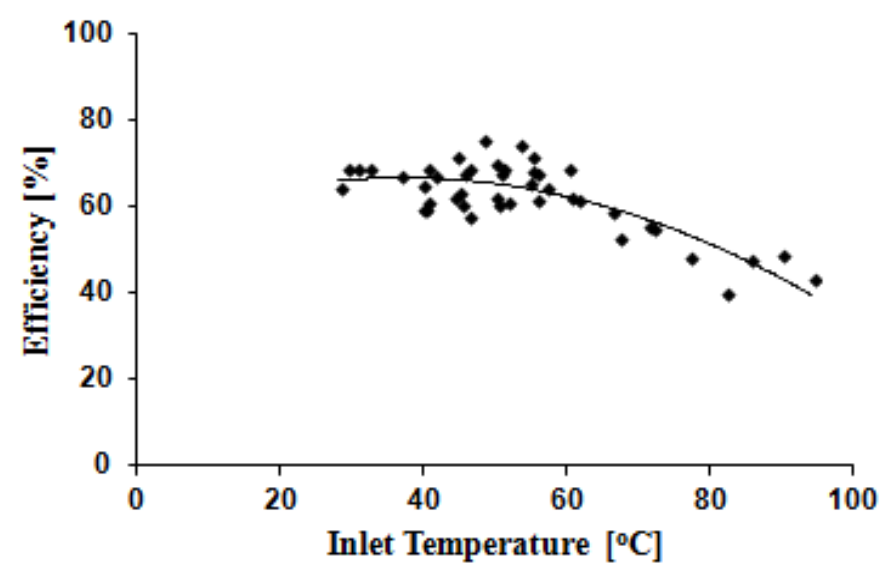

FIGURE 4. Efficiency according to the inlet temperature into the solar collector.

Major differences between inlet and outlet temperatures were obtained in the first three collectors, thus resulting in the highest efficiencies. In the last collector, with inlet mean maximum temperature (T4) around $57^{\circ} \mathrm{C}$, and outlet mean temperature (T5) around $63{ }^{\circ} \mathrm{C}$, efficiency is lower due to the proximity of temperatures, that is, poor heat transfer. YOU \& HU (2002) reported similar results for the same outlet temperature, i.e., the higher the temperature of the collector inlet fluid, the lower the obtained efficiency. 
The results indicate that efficiency of the solar collector is proportional to the ratio between the working fluid mean temperature and room temperature, for a given incident solar radiation; thus, the higher the inlet fluid temperature, the lower the system efficiency.

\section{Economic evaluation}

Considering 65\% efficiency for the reduced temperature lower than $0.04 \mathrm{~m}^{2} \mathrm{~K} / \mathrm{W}$, which was determined in the tests with solar collectors, we proceeded to the financial viability analysis of the solar system use for water pre-heating in boilers.

According to RETScreen 4 software, the region of Chapecó presents a mean daily radiation of $4.64 \mathrm{kWh} / \mathrm{m}^{2}$, which is equal to $16,704 \mathrm{~kJ} / \mathrm{m}^{2}$. Therefore, every meter of solar collector produces, on average, $10,857.6 \mathrm{~kJ} / \mathrm{m}^{2}$ per day that, when multiplied by 365 days, amounts to $3,963,024 \mathrm{~kJ} / \mathrm{m}^{2}$ per year. Considering the same amount of firewood, in kilograms, that is used to obtain the same energy, there were, on average, $590.25 \mathrm{~kg}$ of firewood, under the market value of $\mathrm{R} \$ 0.1923 / \mathrm{kg}$, what results in annual fuel savings of R $\$ 113.51$. The analysis for LPG and electricity fuels is shown in Table 2.

TABLE 2. Comparison among three fuels for water pre-heating in boilers.

\begin{tabular}{cccc}
\hline & Firewood & LPG & Electricity \\
\hline Calorific power $(\mathrm{kJ} / \mathrm{kg})$ & $12,207.0$ & $48,185.0$ & - \\
Efficiency $(\%)$ & 55 & 70 & 90 \\
Consumption per $\mathrm{m}^{2}$ of collector & $590.25 \mathrm{~kg}$ & $117.49 \mathrm{~kg}$ & $1,223.16 \mathrm{kWh}$ \\
Unit cost $(\mathrm{R} \$)$ & 0.1923 & 2.99 & 0.3987 \\
Total $(\mathrm{R} \$)$ & 113.51 & 351.30 & 487.71 \\
\hline
\end{tabular}

OLIVIER et al. (2008), who evaluated the economic viability of solar collector installation in relation to diesel use in a power plant in Antarctica, reported the economy of 12,244 liters of fuel after the implementation of flat-plate solar collectors; the authors suggest that this system may be used in addition to other forms of power generation to reduce expenses.

For cost purposes, a demonstration was created for an installation requiring 190,225.15 MJ per year, i.e., a demand of 20 solar collectors. For calculation purposes, the proposed solar system is automated to optimize power consumption, with a pump triggering command for water circulation according to the temperature differential between the solar collectors and water tank, what generated a total cost of the solar heating system installation and implementation of $\mathrm{R} \$ 92,800.00$. The fixed costs for the solar system operation are low and may be disregarded in the calculation. For the comparison of cost reduction between the proposed system and the other three fuels, the annual cost of each was calculated, resulting in R $\$ 29,443.20$ for firewood, R\$ 16,862.16 for LPG, and $\mathrm{R} \$ 23,410.28$ for electricity.

For calculation of the investment payback, as well as comparison between present and future values, we used $10 \%$ as the rate of cost increase (Table 3).

TABLE 3. Payback values for implementation of the solar collector for water pre-heating in boilers regarding three fuels.

\begin{tabular}{cc}
\hline Fuel & Payback (years) \\
\hline Firewood & 3.97 \\
LPG & 8.40 \\
Electricity & 5.31 \\
\hline
\end{tabular}

The payback values are considered interesting for application because, according to a supplier of solar heating pipes, this system life lasts, approximately, 20 years, with warranty up to seven years; the investment would then be paid within the warranty period, except for LPG, what is 
characterized as a great investment in the case of firewood and electricity replacement. Regarding firewood, it is important to emphasize that it should be stored within reach, what often sacrifices the necessary space for industrial activity. It also requires protection against rain and moisture. If deposited at greater distances, it demands extra labor to be put in the boiler. Besides, the storage of firewood generates a breeding spot for vectors, what requires frequent fumigation (BRAZIL, 2005).

Another obvious factor regarding the use of solar heaters, when replacing other forms of energy, is the environment preservation. To emphasize this statement, we estimated how many kilograms of carbon dioxide would no longer be emitted to the atmosphere when firewood and LPG are replaced. From the knowledge on carbon percentage (KLOCK et al., 2005), the fuel amount saved per $\mathrm{m}^{2}$ of solar collector was 2,162.16 kg/year. For LPG, considering the butane as its main constituent, the value was $356.54 \mathrm{~kg} /$ year. We may observe that the use of solar energy prevents large amounts of greenhouse gases from reaching the atmosphere, and enables the preservation or other uses of fertile lands cultivated with timber. In this sense, the use of such energy also reduces the consumption of LPG, which is a non-renewable fuel, and electricity, reducing the pressure for the construction of new hydroelectric plants. This could hinder the construction of new hydroelectric plants, what changes the characteristics of aquatic and terrestrial environments, thus reducing biodiversity.

\section{CONCLUSIONS}

The performance demonstrated by the solar collectors for different radiation values, and fluid inlet and room temperatures indicated a better working range when the inlet fluid temperature in the collector is below $57^{\circ} \mathrm{C}$, as most tests presented heat exchange efficiency around $65 \%$. This proves to be suitable for new applications, such as thermal plants and heating at high temperatures for industrial processes.

Assuming that solar energy, for water pre-heating in boilers, is used to replace conventional methods, the return time on investment for boilers, in comparison with firewood, LPG, and electricity, was 4; 7 and 5 years, respectively. Such values are considered economically attractive. Moreover, the firewood, which is the most currently used fuel for water heating, requires appropriate locations for storage and increased manpower. Regarding the environmental gains from the use of solar energy, we may cite: reduction of greenhouse gas release, generated in the combustion of conventional fuels; preservation of areas that would be cleared for timber cultivation; and, in the case of electricity, a decreased need for new hydroelectric plants, which affect the population life quality and the entire biotic environment in the surroundings.

\section{REFERENCES}

ABENSUR, E. O. Um modelo multiobjetivo de otimização aplicado ao processo de orçamento de capital. Gestão \& Produção, São Carlos, v. 19, n. 4, p. 747-758, 2012.

ABNT. Associação Brasileira de Normas Técnicas. NBR 15.569. Sistema de aquecimento solar de água em circuito direto - projeto e instalação. Rio de Janeiro, 2008.

ABRAMOVAY, R. Desenvolvimento sustentável: qual a estratégia para o Brasil? Novos Estudos, São Paulo, n. 87, p. 97-113, jul. 2010.

ALTOÉ, L.; OLIVEIRA FILHO, D.; CARLO, J. C. Análise energética de sistemas solares térmicos para diferentes demandas de água em uma residência unifamiliar. Ambiente Construído, São Paulo, v. 12, n. 3, p. 75-87, jul./set. 2012.

APRICUS. Site oficial da empresa. Disponível em: <www.apricus.com>. Acesso em: 15 jan. 2012.

ARRUDA, L. B. Operação de sistemas de aquecimento solar de água com controle de vazões em coletores planos. 2004. 230 f. Tese (Doutorado) - Escola Politécnica, Universidade de São Paulo, São Paulo, 2004. 
BARON, S.; RENK, A. A. UHE Foz do Chapecó: estratégias dos agentes envolvidos e o desenvolvimento regional. Revista Brasileira de Planejamento e Desenvolvimento, Curitiba, v. 1, p.114-125, jul./dez. 2012.

BERGMAN, T. L.; LAVINE, A. S.; INCROPERA, F. P.; DEWITT, D. P. Fundamentals of heat and mass transfer. $7^{\text {th }}$ ed. New Jersey: John Wiley \& Sons, 2011. 1080 p.

BERMANN, C. O projeto da Usina Hidrelétrica Belo Monte: a autocracia energética como paradigma. Novos Cadernos NAEA, Belém, v. 15, n. 1, p. 5-23, 2012.

BRASIL. Ministério da Saúde. Secretaria de Vigilância em Saúde. Guia de vigilância epidemiológica. 6.ed. Brasília, 2005.

DINIZ, E. M.; BERMANN, C. Economia verde e sustentabilidade. Estudos Avançados. São Paulo, v. 26, n. 74, p. 323-329, 2012.

GIORGETTI, M. F. Fundamentos de fenômenos de transporte para engenharia. São Carlos: Suprema Gráfica e Editora, 2008. 500 p.

GOLDEMBERG, J.; LUCON, O. Energias renováveis: um futuro sustentável. Revista USP, São Paulo, n. 72, p. 6-15, dez./fev. 2007.

IEA. International Energy Agency. Key world energy statistics 2011. Paris, 2011.

KALOGIROU, S. A. Solar thermal collectors and applications. Progress in Energy and Combustion Science, Oxford, v. 30 p. 231-295, 2004.

KLOCK, U.; MUÑIZ, G. I. B.; HERNANDEZ, J. A.; ANDRADE, A. S. Química da madeira. 3.ed. Curitiba: Universidade Federal do Paraná, 2005. 81 p.

LEEPHAKPREEDA, T. Study of conversion efficiency of tube-type solar thermal collectors. Thammasat International Journal of Science and Technology, Oxford, v. 15, n. 2, p. 10-16, 2010.

LIN, W.; GAO, W.; LIU, T. A parametric study on the thermal performance of cross-corrugated solar air collectors. Applied Thermal Engineering, v. 26, n. 10, p. 1043-1053, 2006.

LUNA, A.; VELÁZQUEZ, N.; GALLEGOS, R.; BOJORQUEZ, G. Aire acondicionado solar para conjunto de viviendas en Mexicali, México. Información Tecnológica, México, v. 19, n. 1, p. 45-56, 2008.

MENDES, T. A.; RODRIGUES FILHO, S. Antes do pré-sal: emissões de gases de efeito estufa do setor de petróleo e gás no Brasil. Estudos Avançados, São Paulo, v. 26, n. 74, p. 201-218, 2012.

OLIVEIRA, L. F. C. de; FERREIRA, R. de C.; ALMEIDA, R. de A.; LOBATO, E. J. V.; MEDEIROS, A. M. Potencial de redução do consumo de energia elétrica pela utilização de aquecedores solares no Estado de Goiás. Engenharia Agrícola, Jaboticabal, v. 28, n. 3, p. 406-416, 2008.

OLIVIER, J. R.; HARMS, T. M.; ESTERHUYS, D. J. Technical and economic evaluation of the utilization of solar energy at South Africa's SANAE IV base in Antarctica. Renewable Energy, Oxford, v.33, p. 1073-1084, 2008.

PERES, A. A. C.; VÁSQUEZ, H. M.; SOUZA, P. M.; SILVA, J. F. C.; VILLELA, O. V.; SANTOS, F. C. Análise financeira e de sensibilidade de sistemas de produção de leite em pastagem. Revista Brasileira de Zootecnia, Viçosa - MG, v. 38, n. 10, p. 2072-2078, 2009.

QUEIROZ, A. R. S.; MOTTA-VEIGA, M. Análise dos impactos sociais e à saúde de grandes empreendimentos hidrelétricos: lições para uma gestão energética sustentável. Ciência \& Saúde Coletiva, Rio de Janeiro, v. 17, n. 6, p. 1387-1397, jan./jun. 2012.

QUERINO, C. A. S.; MOURA, M. A. L.; KAYSE, J.; QUERINO, A. S.; VON RADOW, C.; MARQUES FILHO, A. O. Estudo da radiação solar global e do índice de transmissividade (kt), 
externo e interno, em uma floresta de mangue em Alagoas- Brasil. Revista Brasileira de Meteorologia, São José dos Campos, v. 26, n. 2, p. 204-294, 2011.

SILVA, M. L.; FONTES, A. A. Discussão sobre os critérios de avaliação econômica: valor presente líquido (VPL), valor anual equivalente (VAE) e valor esperado da terra (VET). Revista Árvore, Viçosa - MG, v.29, n. 6, p. 931-936, 2005.

YOU, Y.; HU, E. J. A medium-temperature solar thermal power system and its efficiency optimization. Applied Thermal Engineering, Oxford, v. 22, p. 357-364, 2002. 